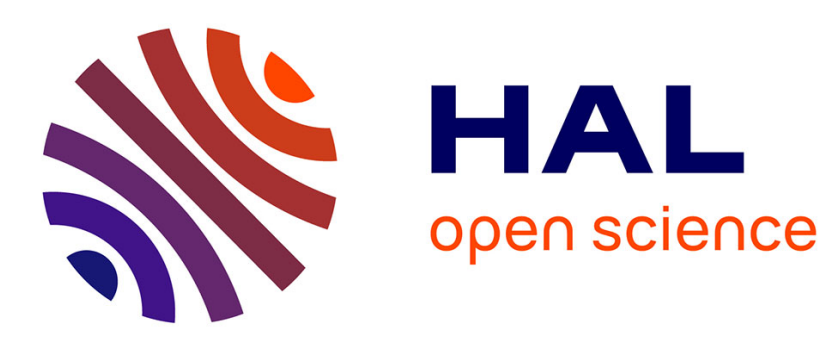

\title{
Purification and properties of an endo-(1-4) B-D-xylanase from Irpex lacteus (Polyporus tulipiferae)
}

Christine Hoebler, J.M. Brillouet

\section{To cite this version:}

Christine Hoebler, J.M. Brillouet. Purification and properties of an endo-(1-4) B-D-xylanase from Irpex lacteus (Polyporus tulipiferae). Carbohydrate Research, 1984, 128, pp.141-155. hal-02726789

\section{HAL Id: hal-02726789 \\ https://hal.inrae.fr/hal-02726789}

Submitted on 2 Jun 2020

HAL is a multi-disciplinary open access archive for the deposit and dissemination of scientific research documents, whether they are published or not. The documents may come from teaching and research institutions in France or abroad, or from public or private research centers.
L'archive ouverte pluridisciplinaire HAL, est destinée au dépôt et à la diffusion de documents scientifiques de niveau recherche, publiés ou non, émanant des établissements d'enseignement et de recherche français ou étrangers, des laboratoires publics ou privés. 


\section{PURIFICATION AND PROPERTIES OF AN ENDO-( $1 \rightarrow 4)-\beta$-D-XYLANASE FROM Irpex lacteus (Polyporus tulipiferae)}

CHRISTINE HoEbler AND JEAN-MARC BRILLOUET*

Institut National de la Recherche Agronomique, Centre de Recherches Agro-Alimentaires, Laboratoire de Biochimie et Technologie des Glucides, Rue de la Géraudière, 44072 Nantes Cédex (France)

(Received July 28th, 1983; accepted for publication, November 15th, 1983)

\section{ABSTRACT}

A xylanase from Driselase (a commercial enzyme preparation), obtained from the basidiomycetes Irpex lacteus (Polyporus tulipiferae), was purified $\sim 32$ fold by desalting on Sephadex G-25, ion-exchange chromatography on DEAESepharose CL-6B and CM-Sepharose CL-6B, hydrophobic-interaction chromatography on Phenyl-Sepharose CL-4B, gel filtration on Ultrogel AcA54, and affinity chromatography on Concanavalin A-Ultrogel. The enzyme is a glycoprotein that contains $23 \%$ of sugars, mainly as glucose. Its molecular weight is 38,000 and its pI 7.6-8.0. The enzyme exhibited maximal activity at $\mathrm{pH} 4.6-5.2$ and at $60^{\circ}$, and was completely inactivated within $30 \mathrm{~min}$ at $70^{\circ}$. The $K_{\mathrm{m}}$ values for larch $4-O-$ methylglucuronoxylan were 2.8 (suspension in water) and $1 \mathrm{mg} / \mathrm{mL}$ (solution in $20 \%$ methyl sulfoxide). The xylanase degraded larchwood xylan to xylose, xylobiose, and xylotriose, as neutral end-products.

\section{INTRODUCTION}

Xylans are the major hemicellulosic polysaccharides occurring in such lignocellulosic waste-materials ${ }^{1}$ as straws from the Gramineae, bagasse, and husks. They contain a backbone of $(1 \rightarrow 4)$-linked $\beta$-D-xylosyl residues to which are attached $^{2,3}$ single $4-O$-methyl-D-glucosyluronic acid groups at $0-2$ and/or $\alpha$-Larabinofuranosyl groups at $\mathrm{O}-3$, or extended side-chains carrying arabinosyl and xylosyl residues ${ }^{4}$.

Xylanases (EC 3.2.1.8.) are endo-enzymes, which can cleave the $(1 \rightarrow 4)-\beta$-Dxylopyranosyl linkages of xylans, and are found mainly in fungi, but also occur in bacteria, insects, and plants ${ }^{5}$. Xylanases associated with cellulases are the major components responsible for the biodegradation of lignocellulosic materials. The use of homogeneous xylanases as highly specific tools for elucidating the structure of alkali-extracted xylans ${ }^{6}$, as well as the organisation of intact cell-walls of plants ${ }^{7}$, is very promising.

\footnotetext{
*To whom correspondence should be addressed.
} 
Nisizawa et al. ${ }^{8-10}$ and Kanda et al. ${ }^{11-16}$ have studied in detail the cellulases from the basidiomycetes Irpex lacteus (Polyporus tulipiferae). We now describe the purification and properties of an endo-( $1 \rightarrow 4)-\beta$-D-xylanase from this fungus.

\section{RESULTS AND DISCUSSION}

Purification (See Table I). - Ion-exchange chromatography of a xylanase from Irpex lacteus (Polyporus tulipiferae) on DEAE-Sepharose CL-6B gave a 5fold purification and removed most of the coloured material. Of the original xylanolytic activity, $\sim 67 \%$ remained unbound, and $\sim 80 \%$ of the original protein material was eliminated.

Further ion-exchange chromatography on CM-Sepharose CL-6B at pH 4.4 gave a major, broad xylanase peak that was eluted by $\sim 0.15 \mathrm{M}$ sodium chloride (Fig. 1). It contained $\sim 39 \%$ of the original activity, and $\sim 80 \%$ of the injected proteins were removed (purification 14-fold). Successive dialyses against mm phosphate buffer (12 h, pH 7.0) and 20mM acetate buffer ( $2.5 \mathrm{~h}, \mathrm{pH} 4.4)$ were necessary for reproducibility of the subsequent chromatography on CM-Sepharose. The du-

\section{TABLE I}

PURIFICATION OF XYLANASE FROM COMMERCIAL "DRISELASE"

\begin{tabular}{|c|c|c|c|c|c|c|c|}
\hline Step & $\begin{array}{l}\text { Volume } \\
(m L)\end{array}$ & $\begin{array}{l}\text { Activity } \\
\text { (nkat. } \\
\left.m L^{-1}\right)\end{array}$ & $\begin{array}{l}\text { Protein } \\
(m g . \\
\left.m L^{-1}\right)\end{array}$ & $\begin{array}{l}\text { Specific } \\
\text { activity } \\
\text { (nkat. } \\
\left.m g^{-1}\right)\end{array}$ & $\begin{array}{l}\text { Total } \\
\text { activity } \\
\text { (nkat) }\end{array}$ & $\begin{array}{l}\text { Yield } \\
(\%)\end{array}$ & $\begin{array}{l}\text { Purification } \\
\text { (fold) }\end{array}$ \\
\hline $\begin{array}{l}\text { Crude enzyme } \\
\text { Desalting on }\end{array}$ & 23 & 1404 & 57.8 & 24.3 & 32300 & 100 & - \\
\hline $\begin{array}{l}\text { Sephadex G-25M } \\
\text { Ion-exchange } \\
\text { chromatography on } \\
\text { DEAE-Sepharose }\end{array}$ & 66 & 478 & 14.1 & 34.0 & 31570 & 97.7 & 1.4 \\
\hline $\begin{array}{l}\text { CL-6B } \\
\text { Ion-exchange } \\
\text { chromatography on } \\
\text { CM-Sepharose }\end{array}$ & 158 & 138 & 1.13 & 122 & 21750 & 67.3 & 5 \\
\hline $\begin{array}{l}\text { CL-6B } \\
\text { Hydrophobic-inter- } \\
\text { action } \\
\text { chromatography } \\
\text { on Phenyl- }\end{array}$ & 196 & 63.7 & 0.19 & 335 & 12490 & 38.7 & 14 \\
\hline $\begin{array}{l}\text { Sepharose CL-4B } \\
\text { Gel filtration } \\
\text { on Ultrogel }\end{array}$ & 100 & 78.3 & 0.12 & 652 & 7834 & 24.2 & 26 \\
\hline $\begin{array}{l}\text { AcA54 } \\
\text { Affinity } \\
\text { chromatography on } \\
\text { Concanavalin A- } \\
\text { Ultrogel AcA22 }\end{array}$ & 26 & 227 & 0.31 & 732 & 5905 & 18.3 & 30 \\
\hline
\end{tabular}




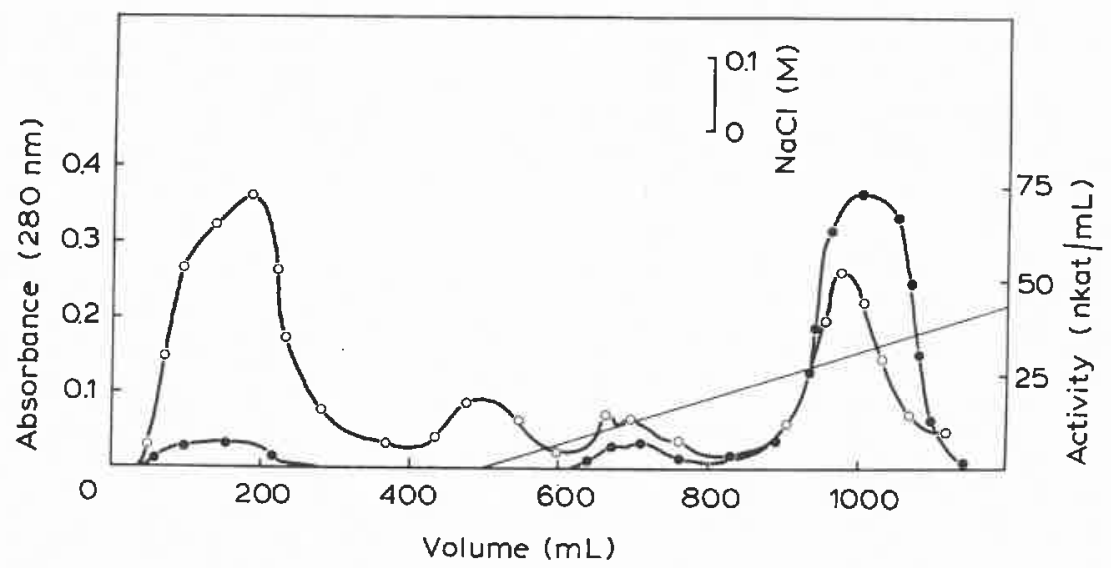

Fig. 1. Ion-exchange chromatography of the Irpex lacteus xylanase on CM-Sepharose CL-6B (see Experimental). Fractions $(5 \mathrm{~mL})$ were assayed for protein at $280 \mathrm{~nm}(-\mathrm{O}-)$ and xylanase activity $(-1-)$.

ration of the second dialysis step was critical, because the xylanase was unstable under these conditions.

Attempts to purify the xylanase by chromatofocusing on PBE 118 (Pharmacia) were unsuccessful, because most of the activity did not bind to the exchanger even at a $\mathrm{pH}$ as high as 11.0. Thus, the enzyme had a low density of ionisable groups over a wide $\mathrm{pH}$-range; on hydrophobic-interaction chromatography, it was bound to Phenyl-Sepharose CL-4B, $\sim 62 \%$ of the injected activity being eluted as a sharp peak (Fig. 2) at $\sim 25 \%$ ethylene glycol ( $\sim 37 \%$ of injected protein). An inactive fraction of low molecular weight was eliminated by gel filtration on Ultrogel AcA54 (Fig. 3).

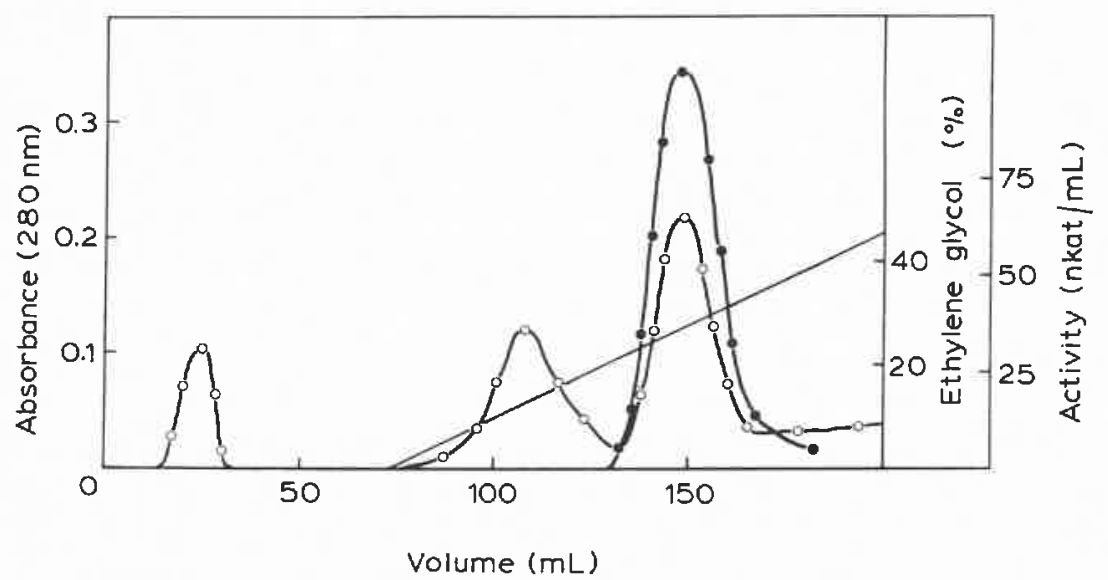

Fig. 2. Hydrophobic-interaction chromatography of the xylanase on Phenyl-Sepharose CL-4B (see Experimental). Fractions $(2 \mathrm{~mL})$ were assayed for protein at $280 \mathrm{~nm}(-\mathrm{O}-$ ) and xylanase activity (-)- 


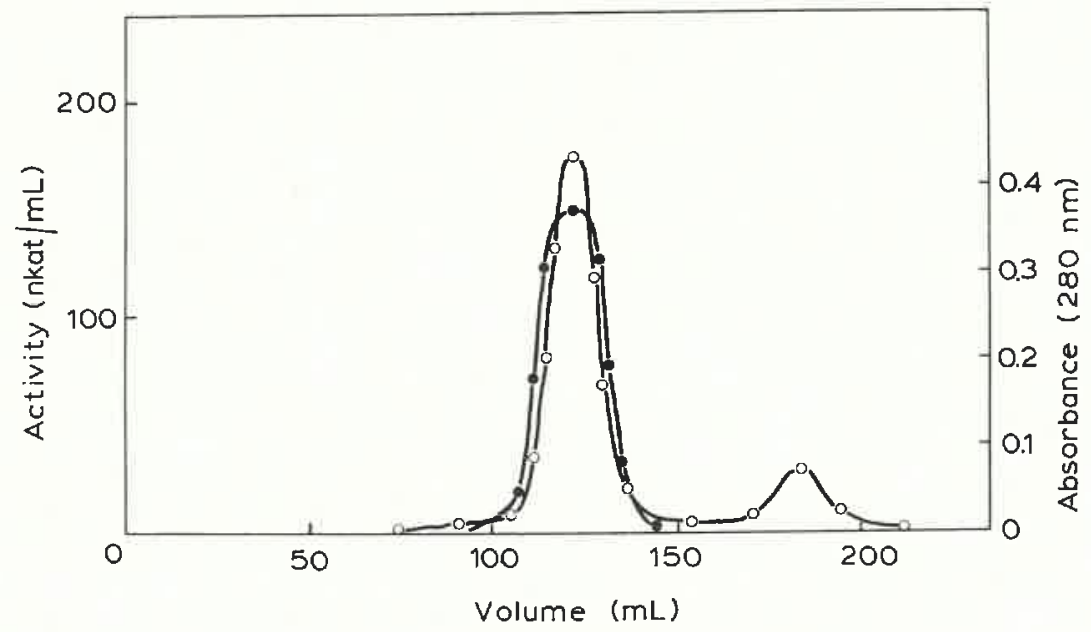

Fig. 3. Gel filtration of the xylanase on Ultrogel AcA54 (see Experimental). Fractions (1.2 mL) were assayed for protein at $280 \mathrm{~nm}(-\mathrm{O}-)$ and xylanase activity $(-\odot-)$.

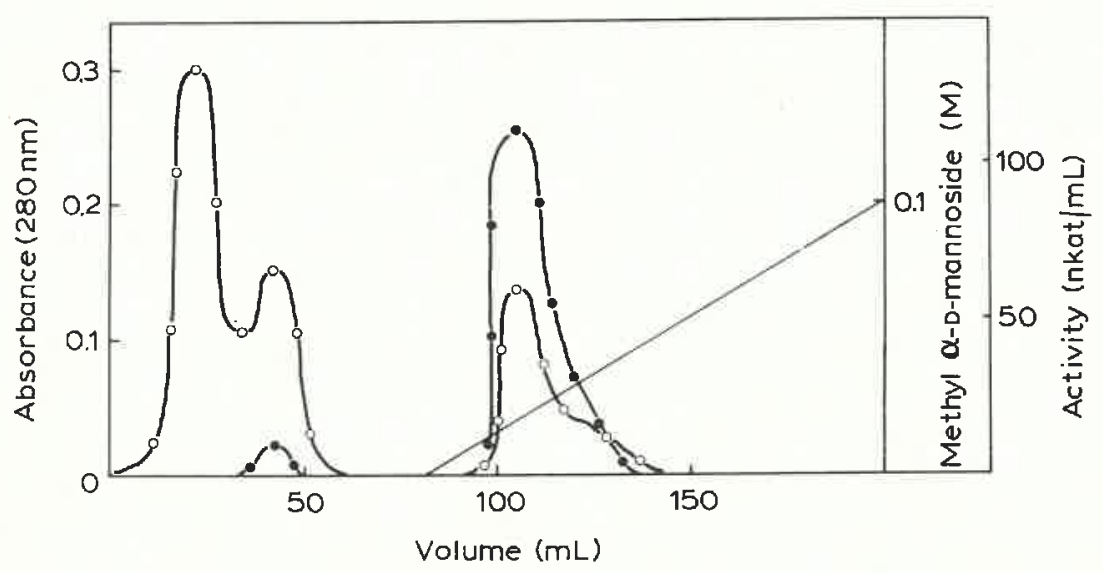

Fig. 4. Affinity chromatography of the xylanase on Concanavalin A-Ultrogel AcA22 (see Experimental). Fractions $(1.5 \mathrm{~mL})$ were assayed for protein at $280 \mathrm{~nm}(-\mathrm{O}-)$ and xylanase activity $(--)$.

Final purification involved lectin-affinity chromatography on Concanavalin A-Ultrogel AcA22 (Fig. 4). The xylanase was firmly bound and was not eluted with $\mathrm{M}$ sodium chloride. Methyl $\alpha$-D-mannopyranoside released the xylanase in $\sim 50 \%$ yield for both injected protein and activity.

The purified xylanase had $\sim 10 \%$ of the original activity (corresponding to a 32-fold purification), had a specific activity of $778 \mathrm{nkat}_{\mathrm{mg}}{ }^{-1}$, and gave a single, diffused protein band on SDS-polyacrylamide gel electrophoresis and electrofocusing; it had no activity against various oligomeric and polymeric substrates, but showed a very low and variable activity $(<0.7 \%$ ) against $o$-nitrophenyl $\beta$-Dxylopyranoside. 
Properties. - Some of the properties of the xylanase are reported in Table II. The molecular weight, as determined by SDS-polyacrylamide gel electrophoresis and by gel filtration on Ultrogel AcA54 (Fig. 3), was 38,000. The isoelectric point was difficult to determine, because of the low density of ionisable groups over a wide $\mathrm{pH}$-range, and the enzyme did not focus even after long runs; only a pI range of $7.6-8.0$ could be proposed. As compared to other fungal xylanases ${ }^{17-20}$, the Irpex lacteus xylanase was richest in hydrophobic and acidic amino acids (Table III); it was devoid of cysteine, reflecting the lack of inhibition by $N$-ethylmaleimide (see below). The xylanase contained $23 \%$ of sugars. G.1.c. of the derived alditol acetates revealed glucose and mannose in the ratio 13:1. The preponderance of glucose over mannose explains the easy release of the enzyme from Concanavalin A-Ultrogel by methyl $\alpha$-D-mannopyranoside, because glucose has a far lower affinity for Con $\mathrm{A}$ than that of $\alpha$-D-mannose ${ }^{21}$.

\section{TABLE II}

PROPERTIES OF XYLANASE

\begin{tabular}{|c|c|}
\hline Property & Xylanase \\
\hline Molecular weight ${ }^{a}$ & 38,000 \\
\hline pI & $7.6-8.0$ \\
\hline Carbohydrate $^{b}(\%)$ & $23(\mathrm{Glc} / \mathrm{Man}=13: 1)$ \\
\hline pH optimum & $4.6-5.2$ \\
\hline$\theta$ optimum $\left({ }^{\circ}\right)$ & 60 \\
\hline \multicolumn{2}{|l|}{ Larch 4-O-methylglucuronoxylan } \\
\hline$V_{\max }\left(40^{\circ}, \mathrm{pH} 4.2\right)\left(\right.$ nkat.mg $\left.{ }^{-1}\right)$ & 824 \\
\hline$K_{\mathrm{m}}\left(40^{\circ}, \mathrm{pH} 4.2\right)\left(\mathrm{mg} \cdot \mathrm{mL}^{-1}\right)$ & 2.8 \\
\hline$V_{\max }\left(40^{\circ}, 20 \% \mathrm{Me}_{2} \mathrm{SO}, \mathrm{pH} 4.2\right)^{c}$ (nkat.mg ${ }^{-1}$ ) & 934 \\
\hline$K_{\mathrm{m}}\left(40^{\circ}, 20 \% \mathrm{Me}_{2} \mathrm{SO}, \mathrm{pH} 4.2\right)\left(\mathrm{mg} \cdot \mathrm{mL}^{-1}\right)$ & 1.0 \\
\hline
\end{tabular}

${ }^{a}$ Determined by SDS-polyacrylamide gel electrophoresis. ${ }^{b}$ Determined by the phenol-sulfuric acid method. 'Larch xylan was dissolved in pure $\mathrm{Me}_{2} \mathrm{SO}$ and then diluted to $20 \%$ in the standard assay.

TABLE III

AMINO ACID PROFILE OF Irpex lacteus XYLANASE

\begin{tabular}{lcll}
\hline Amino acid $^{a}$ & Mole $(\%)$ & Amino acid & Mole (\%) \\
\hline Aspartic acid & 10.8 & Isoleucine & 2.7 \\
Threonine & 5.9 & Leucine & 7.6 \\
Serine & 13.5 & Tyrosine & 1.3 \\
Glutamic acid & 12.3 & Phenylalanine & 4.1 \\
Proline & 4.0 & Lysine & 4.0 \\
Glycine & 13.0 & Histidine & 2.5 \\
Alanine & 11.2 & Arginine & 1.2 \\
Valine & 5.9 & & \\
\hline
\end{tabular}

${ }^{a}$ Tryptophan was not determined. 

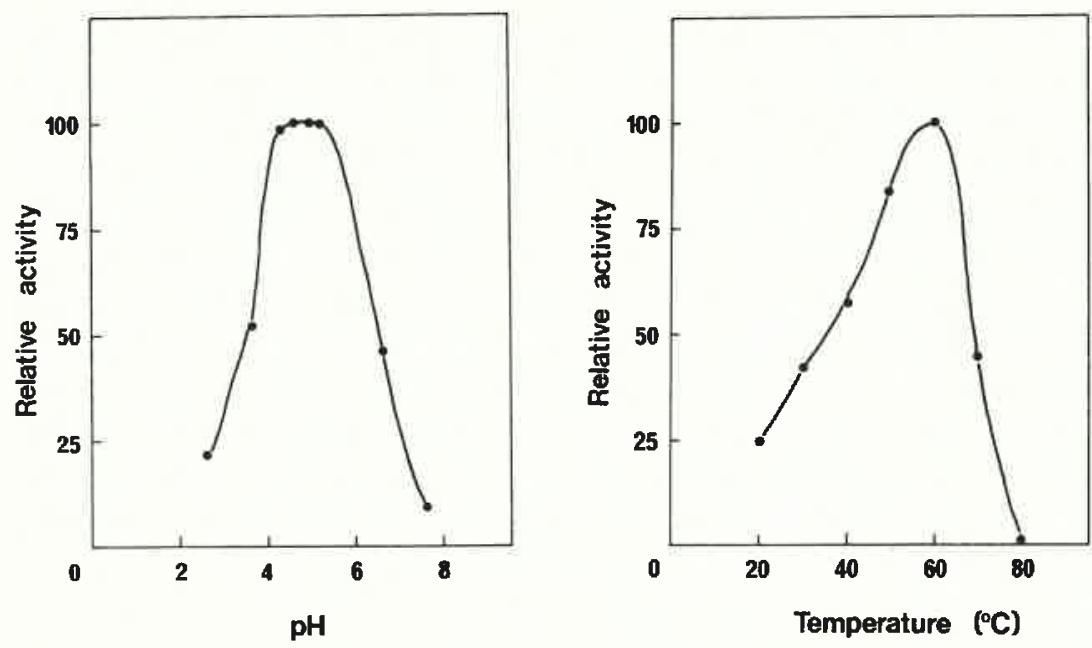

Fig. 5. Effect of pH on enzyme activity (see Experimental).

Fig. 6. Effect of temperature on enzyme activity (see Experimental).
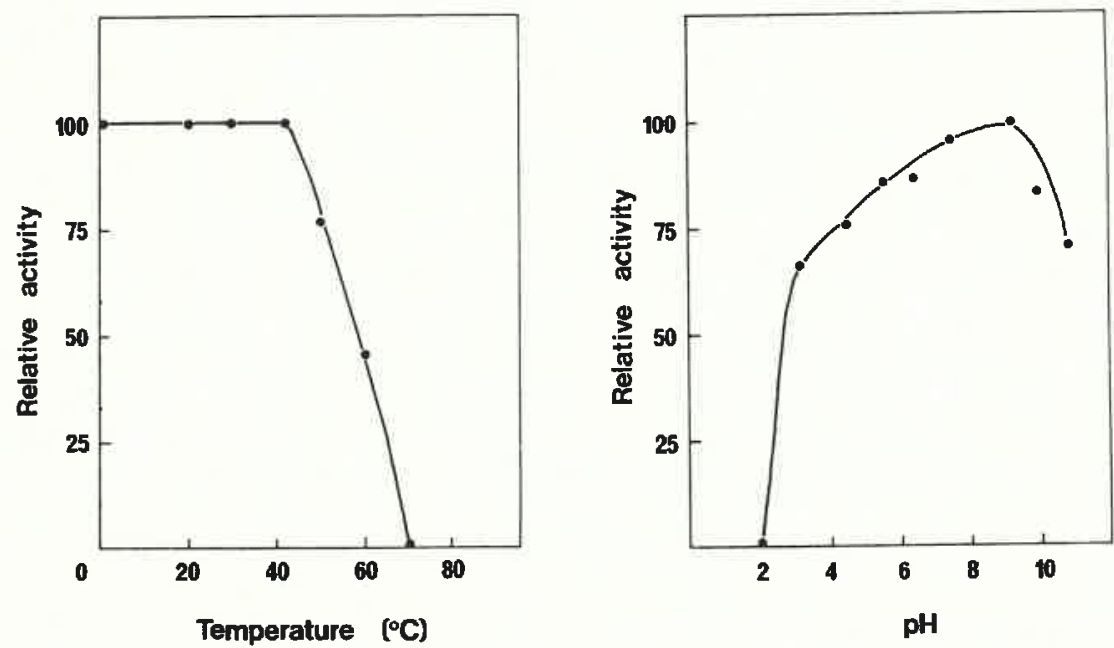

Fig. 7. Effect of temperature on enzyme stability (see Experimental).

Fig. 8. Effect of pH on enzyme stability (see Experimental).

The enzyme exhibited maximum activity in the $\mathrm{pH}$ range 4.6-5.2 (Fig. 5) and at $60^{\circ}$ in 20 -min assays (Fig. 6), was inactivated after $30 \mathrm{~min}$ at $70^{\circ}$ (Fig. 7), was stable in the $\mathrm{pH}$ range $6.5-9.0$ (the stability decreasing gradually from $\mathrm{pH} 6.0$ to 3.5 ), and was rapidly inactivated at $\mathrm{pH}<3.0$ and $>10.5$ (Fig. 8). 
Of the metal ions tested (Table IV), only $\mathrm{Ca}^{2+}$ significantly increased the activity $(\sim 30 \%)$; the activation of xylanases by $\mathrm{Ca}^{2+}$ has been reported ${ }^{22,23}$. The enzyme was inhibited by $\mathrm{mM} \mathrm{Hg}^{2+}$ and $\mathrm{Ag}^{+}$. Inhibition by $\mathrm{Hg}^{2+}$ in the absence of cysteine may indicate the involvement of tryptophan units in the maintenance of enzyme activity ${ }^{23}$. There were difficulties in measuring the inhibition caused by $\mathrm{Fe}^{2+}$, because of the formation of insoluble salts with 4- $O$-methylglucuronate from the larch xylan. Tryptophan, which was not determined in this study, must occur in the xylanase because 2-hydroxy-5-nitrobenzyl bromide (Table V), a specific agent for tryptophan, totally inhibited the xylanase activity. As shown by partial inhibition of the enzyme by $N$-acetylimidazole, tyrosine units are probably involved in the xylanase catalysis. EDTA did not significantly inhibit the enzyme. The xylanase from Irpex lacteus reacts to these various inhibitors in a manner very similar to that of the Trametes hirsuta xylanase.

\section{TABLE IV}

EFFECT OF METAL IONS ON XYLANASE

\begin{tabular}{lll}
\hline Ion & $\begin{array}{l}\text { Concentration tested } \\
(\mathrm{mM})\end{array}$ & Relative $^{a}$ activity \\
\hline $\mathrm{Hg}^{2+}$ & 0.01 & 107 \\
& 0.1 & 67 \\
& 1 & 55 \\
$\mathrm{Mn}^{2+}$ & 10 & 35 \\
$\mathrm{Ag}^{+}$ & 1 & 71 \\
$\mathrm{~K}^{+}$ & 1 & 73 \\
$\mathrm{Fe}^{2+}$ & 1 & 100 \\
$\mathrm{Co}^{2+}$ & 1 & 102 \\
$\mathrm{Mg}^{2+}$ & 1 & 108 \\
$\mathrm{Zn}^{2+}$ & 1 & 110 \\
$\mathrm{Ba}^{2+}$ & 1 & 110 \\
$\mathrm{Ca}^{2+}$ & 1 & 117 \\
\hline
\end{tabular}

${ }^{a}$ Relative activity to a reference without ion.

TABLE V

INHIBITION OF XYLANASE BY SPECIFIC INHIBITORS

\begin{tabular}{llr}
\hline Inhibitor & $\begin{array}{l}\text { Concentration tested } \\
(m M)\end{array}$ & Relative $^{a}$ activity \\
\hline$N$-Ethylmaleimide & 20 & 100 \\
$N$-Acetylimidazole & 23 & 56 \\
2-Hydroxy-5-nitrobenzyl bromide & 10 & 0 \\
EDTA $^{b}$ & 50 & 92 \\
\hline
\end{tabular}

${ }^{a}$ Relative activity to a reference without inhibitor. ${ }^{b}$ Ethylenediaminetetra-acetic acid (disodium salt). 
Action on larch 4-O-methylglucuronoxylan. - The larchwood xylan contained $\sim 70 \%$ of xylose and $9 \%$ of 4-O-methylglucuronic acid, as determined by $m$ phenylphenol and carboxyl-reduction of the carbodiimide derivative, and had a d.p. of $\sim 140$, as measured by viscometry in methyl sulfoxide ${ }^{24}\left(30^{\circ}\right)$. Gymnosperm xylans are 4-O-methylglucuronoarabinoxylans containing $14-18 \%$ of $4-O$ methylglucuronic acid attached to O-2, and 5-20\% of arabinofuranose attached to $\mathrm{O}-3$, of xylosyl residues of the main backbone. Arabinose, as well as glucomannan and glucan contaminants were absent from the larch-xylan samples used (Sigma, lots 128C-03641 and 122F-0302; Ega-Chemie, lot 3300649/3) contrary to the findings of other authors ${ }^{20,25,26}$. The purified larchwood-xylan samples still contained $\sim 20 \%$ of polyphenolics, as demonstrated by the strong u.v. absorption at $270-280 \mathrm{~nm}$ after dissolution in acetyl bromide ${ }^{27}$. Furthermore, the xylan was faintly coloured, which could reflect the presence of $\operatorname{lignin}^{28}$. Delignification by such oxidising agents as sodium chlorite, which are known to partially depolymerise hemicelluloses ${ }^{28}$, was therefore omitted. The occurrence of lignin in commercial xylans, either covalently linked or adsorbed, is usually unspecified in enzyme studies ${ }^{7,20,25}$, but must be of some importance. It is possible that hydrophobic interaction between our xylanase and the lignin moiety could play a significant role in the enzyme-substrate interaction. The kinetic parameters were determined (Table II, Figs. 9 and 10) either in standard acetate buffer or in media containing various concentrations of methyl sulfoxide, a solvent for xylans ${ }^{28}$. The $K_{\mathrm{m}}$ value was $2.8 \mathrm{mg} / \mathrm{mL}$ in acetate buffer and decreased abruptly to $\sim 1.3 \mathrm{mg} / \mathrm{mL}$ for $10 \%$ methyl sulfoxide. For $20-40 \%$ methyl sulfoxide, the value of $K_{\mathrm{m}}$ was stable at

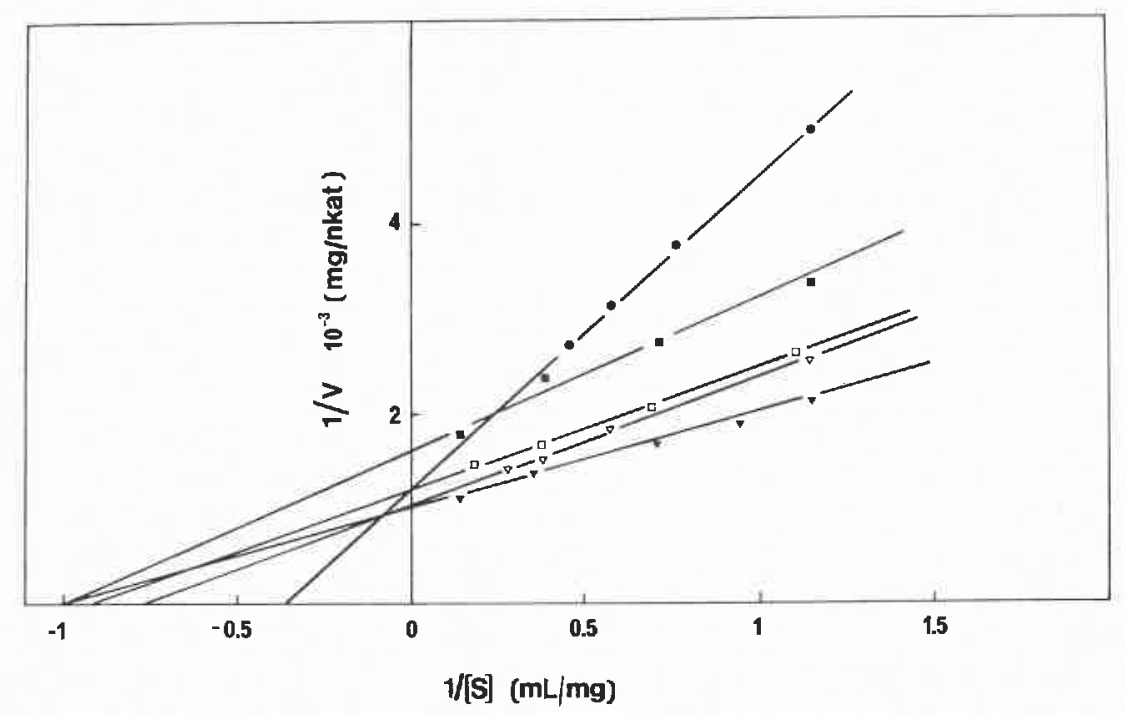

Fig. 9. Lineweaver-Burk plot for the xylanase acting on larch 4- $O$-methylglucuronoxylan (see Experimental): standard conditions (--), the enzyme in the presence of $\mathrm{Me}_{2} \mathrm{SO}, 10 \%(-\nabla-), 20 \%$ $(-\nabla-), 30 \%$ (一 -$)$, and $40 \%$ (一-). 


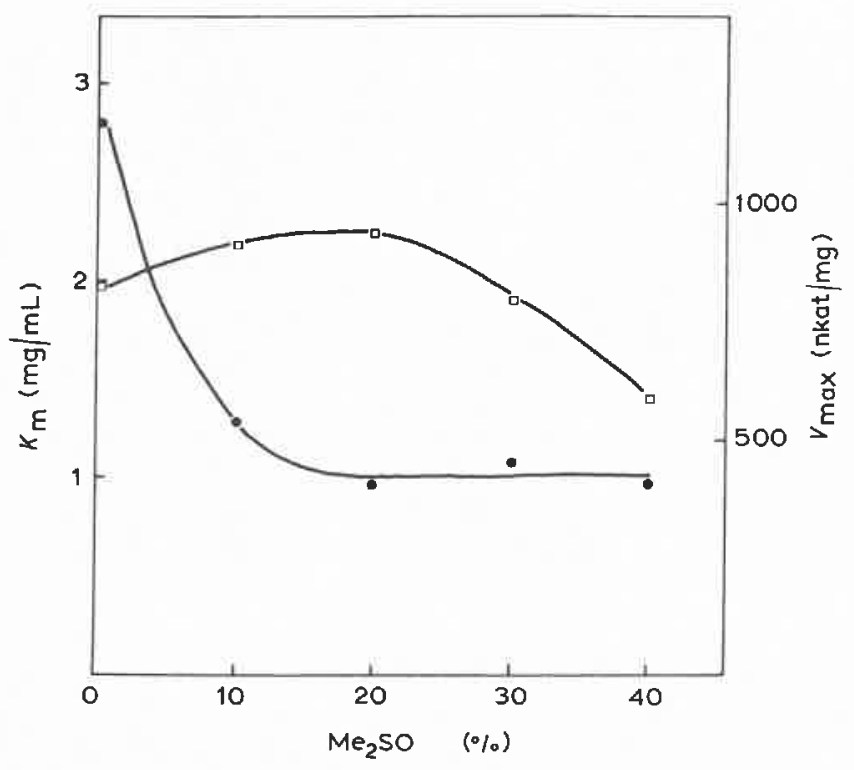

Fig. 10. Variation of $K_{\mathrm{m}}$ (- - ) and $V_{\max }(-\square-)$ for the xylanase acting on larch 4-Omethylglucuronoxylan, as a function of $\mathrm{Me}_{2} \mathrm{SO}$ percentage in the standard activity assay.

$1 \mathrm{mg} / \mathrm{mL}$, which corresponds to $0.7 \mathrm{mg} / \mathrm{mL}$ as $(1 \rightarrow 4)-\beta$-D-xylosidic bonds. This figure is very close to the $K_{\mathrm{m}}$ of Trametes hirsuta xylanase for a very similar watersoluble 4- $O$-methylglucuronoxylan from willow (xylose-uronic acid ratio $=7.6: 1$ ). This greater affinity of Irpex lacteus xylanase for larch 4-O-methylglucuronoxylan in methyl sulfoxide than in water could be related to better solubilisation by the former solvent. This, in turn, could be related to the lack of activity of Aspergillus niger xylanase $\mathrm{e}^{20}$ on water-insoluble, commercial larch xylan ( $\sim 40 \%$ of total commercial xylan). The maximum velocity $V_{\max }$ increased slightly up to $20 \%$ methyl sulfoxide and then decreased gradually as the percentage increased to $40 \%$. Methyl sulfoxide above $20 \%$ therefore acts as a non-competitive inhibitor of the xylanase. No inhibition was observed with $\mathrm{D}$-xylose (mM), L-arabinose (mM), and methyl $\beta$ D-xylopyranoside (mM and $10 \mathrm{mM}$ ).

The hydrolysis of larch 4- $O$-methylglucuronoxylan by the xylanase was monitored by measuring the appearance of reducing sugars, using the Nelson procedure $^{29}$. The reducing power of the medium reached a maximum at $24 \mathrm{~h}$, which corresponded to cleavage of $27 \%$ of the $(1 \rightarrow 4)-\beta$-D-xylosidic bonds. This figure is much smaller than that (49\%) for the hydrolysis of willow xylan by Trametes hirsuta xylanase ${ }^{30}$. Termination of the reaction was not caused by denaturation or inhibition of the xylanase, because it retained its full activity after $55 \mathrm{~h}$. The average d.p. of the oligosaccharides formed was 4.2 , taking into account the neutral and acidic products. Analysis of the neutral components by h.p.l.c. is shown in Fig. 11. 


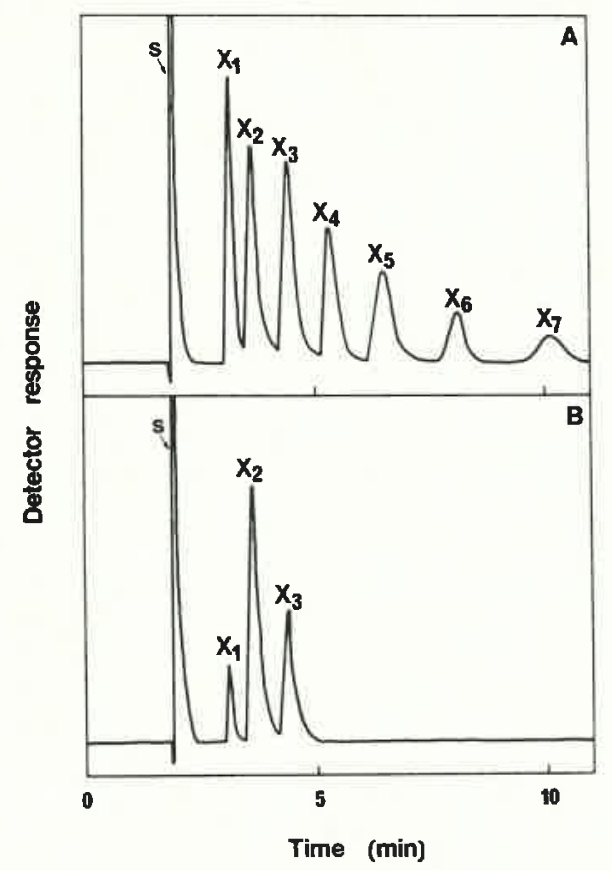

Fig. 11. H.p.l.c. (see Experimental) of $A,(1 \rightarrow 4)-\beta$-D-xylo-oligosaccharides $\left(\mathrm{X}_{1}=\right.$ xylose, $\mathrm{X}_{2}=$ xylobiose, etc.) obtained by partial hydrolysis of larchwood $4-O$-methylglucuronoxylan with $0.03 \mathrm{M}$ trifluoroacetic acid ${ }^{32} ; B$, xylanase hydrolysate.

Xylobiose was the major product, together with xylotriose and xylose; higher neutral homologues were detected, and thus the Irpex lacteus xylanase is concluded to be an endo- $(1 \rightarrow 4)-\beta$-D-xylanase.

\section{EXPERIMENTAL}

Enzyme. - The enzyme was a commercial, crude preparation (Driselase; Kyowa Hakko Kogyo Co., Tokyo) of cell-wall polysaccharidases from the basidiomycetes Irpex lacteus (Polyporus tulipiferae), which is generally used for protoplast preparation.

Substrates. - Commercial larchwood xylan (Sigma) was purified by barium chloride precipitation ${ }^{31}$. The content of neutral sugars was analysed by g.l.c. (on an SP-2340 column ${ }^{32}$ at $225^{\circ}$ ) of the alditol acetate derivatives ${ }^{33}$ obtained after hydrolysis ${ }^{34}$ with $2 \mathrm{M}$ trifluoroacetic acid; acidic sugars were determined by the $m$-phenylphenol colorimetric method ${ }^{35}$. The nature of the acidic sugars was established by carboxyl-reduction of the carbodiimide derivatives ${ }^{36}$ with $\mathrm{NaBH}_{4}$, alditol acetate derivatisation, and g.l.c. The xylan contained one 4- $O$-methylglucuronic acid residue per eight xylosyl residues, according to the data of Aspinall and McKay ${ }^{25}$. Only $\sim 80 \%$ of the dry matter of the purified xylan was identified as polysaccharidic 
material; the remainder was probably polyphenolic, as qualitatively measured by the acetyl bromide procedure ${ }^{27}$.

The other substrates used were carboxymethylcellulose sodium salt (Sigma C-4888, medium viscosity), avicel (Merck), cellulose azure (Calbiochem 219481), arabinan (Koch-Light 52867), larchwood arabinogalactan (Sigma A-2012), polygalacturonic acid (ICN 102771), yeast mannan (Sigma M-7504), dextran (Sigma D-4751), lichenan from Cetraria islandica (Sigma L-8378), laminarin from Laminaria spp. (Fluka 61400), waxy-maize beta-limit dextrin (gift of Dr. P. Colonna), white-lupin acidic galactan (prepared in our laboratory), $p$-nitrophenyl $\alpha$-D-glucopyranoside, $\alpha$-D-galactopyranoside, $\beta$-D-galactopyranoside, $\alpha$-Larabinofuranoside, and $\alpha$-L-fucopyranoside, and $o$-nitrophenyl $\beta$-D-xylopyranoside (Sigma).

Enzyme assay. - Xylanase activity was determined by mixing enzyme solution $(5-200 \mu \mathrm{L},<2$ nkat) with $0.6 \mathrm{~mL}$ of a $1 \%$ dispersion of xylan in $0.1 \mathrm{M}$ acetate buffer ( $\mathrm{pH} 4.2$ ). The volume was made up to $1.2 \mathrm{~mL}$ with distilled water. After incubation for $20 \mathrm{~min}$ at $40^{\circ}$, liberated reducing sugars were measured by the Somogyi-Nelson procedure ${ }^{29}$, using D-xylose as the standard; 1 nkat of enzyme liberated $1 \mathrm{nmol}$ of xylose-equivalent reducing power per second. Other polysaccharidases were measured under similar conditions ( $3 \mathrm{nkat}$ ), but in $0.05 \mathrm{M}$ acetate buffer ( $\mathrm{pH} 5.0$ ) at $30^{\circ}$ for $15 \mathrm{~h}$.

Glycosidases were determined by incubating ${ }^{37} 0.6 \mathrm{~mL}$ of nitrophenyl glycoside $(0.2 \%$ ) in $0.05 \mathrm{M}$ acetate buffer ( $\mathrm{pH} 5.0$ ) with $0.6 \mathrm{~mL}$ of enzyme solution (3 nkat) at $30^{\circ}$ for $15 \mathrm{~h}$. Liberation of $p$ - and $o$-nitrophenol was determined by adding $0.2 \mathrm{~mL}$ of reaction medium in $0.6 \mathrm{~mL}$ of aqueous $20 \%$ sodium carbonate, and measuring the absorbance at $400 \mathrm{~nm}$ for $p$-nitrophenol and at $414 \mathrm{~nm}$ for $o$-nitrophenol.

Protein determination. - Protein was recorded in column effluents at 280 nm. Protein was also measured by the Lowry procedure ${ }^{38}$, using bovine serum albumin (Sigma, Fraction V, A-4503) as reference standard.

General methods. - Polysaccharides were hydrolysed ${ }^{34}$ in $2 \mathrm{M}$ trifluoroacetic acid for $1.25 \mathrm{~h}$ at $120^{\circ}$. The glycosidic moiety of purified xylanase (1 mg) was hydrolysed by boiling in $\mathrm{M}$ hydrochloric acid for $1 \mathrm{~h}^{39}$. Sugars were reduced with sodium borohydride, and the alditols were acetylated with acetic anhydride-pyridine (1:1) at $120^{\circ}$ for $20 \mathrm{~min}^{33,40}$. G.l.c. of alditol acetates was performed ${ }^{32}$ on a glass column $(180 \times 2 \mathrm{~mm}$ i.d.) packed with $3 \%$ of SP-2340 on 100-120 mesh Supelcoport (Supelco) at $225^{\circ}$. Products of the enzymic hydrolysis of larchwood xylan were separated by h.p.t.l.c. with acetonitrile-water $(85: 15)$. Sugars were detected by the diphenylamine-aniline reagent ${ }^{41}$.

Electrophoresis and isoelectric focusing. - SDS-polyacrylamide gel electrophoresis ${ }^{42}$ was performed by using a $10-20 \%$ acrylamide gradient gel at $\mathrm{pH} 8.2$. Protein bands were detected by staining with Coomassie Brilliant Blue G. The molecular weight of the purified xylanase was determined by comparison with a calibration kit (Pharmacia) for low molecular weight protein. 
The isoelectric focusing was performed by using an LKB 2117 Multiphor device, with polyacrylamide plates ${ }^{43}$ containing ampholine of $\mathrm{pH}$ range $8.0-10.5$ (Pharmacia).

Amino acid determination. - The analysis of amino acids was performed by Dr. M. A. O'Neill, using the heptafluorobutyric $n$-propyl derivatisation method ${ }^{44}$ on a dialysed and freeze-dried sample $(200 \mu \mathrm{g})$ of the homogeneous xylanase.

Glycoprotein sugar analysis. - Carbohydrates present in the xylanase were measured by the phenol-sulfuric acid technique ${ }^{45}$ on a desalted and vacuum-concentrated enzyme solution, with D-glucose as the standard.

H.p.l.c. - Samples of xylo-oligosaccharides obtained by enzymic hydrolysis were analysed with a Waters Associates chromatograph equipped with a differential refractometer and a column $(250 \times 4.6 \mathrm{~mm}$ i.d. $)$ packed with Lichrosorb NH2 (particle size, $5 \mu \mathrm{m}$ ) (Merck); elution was effected with acetonitrile-water (70:30) at $2 \mathrm{~mL} / \mathrm{min}$. Prior to analysis, samples were deionised with Dowex 1-X8 $\left(\mathrm{HCOO}^{-}\right)$and Amberlite IR-120 $\left(\mathrm{H}^{+}\right)$resins, and concentrated in vacuo at $40^{\circ}$. The sample size was $25 \mu \mathrm{L}$.

Enzyme purification. - Crude Driselase (5 g) was stirred with $0.1 \mathrm{M}$ phosphate buffer $(25 \mathrm{~mL}, \mathrm{pH} 7.0)$ for $30 \mathrm{~min}$ at $4^{\circ}$. Insoluble material was removed by centrifugation at $40,000 \mathrm{~g}$ for $10 \mathrm{~min}\left(4^{\circ}\right)$, and the supernatant solution was desalted by using a column $(2.2 \times 68 \mathrm{~cm})$ of Sephadex G25 M equilibrated with $0.1 \mathrm{M}$ phosphate buffer ( $\mathrm{pH} 7.0)$.

Chromatography. - (a) On DEAE-Sepharose CL-6B. A column $(3.2 \times 18$ $\mathrm{cm}$ ) of DEAE-Sepharose CL-6B was equilibrated with $10 \mathrm{~mm}$ phosphate buffer ( $\mathrm{pH}$ 7.0). A sample $(66 \mathrm{~mL})$ of the desalted enzyme was dialysed against $10 \mathrm{mM}$ phosphate buffer (pH 7.0) and applied to the column at $160 \mathrm{~mL} / \mathrm{h}$. The xylanase activity remained unbound, whereas most of the coloured material was bound to the anion exchanger.

(b) On CM-Sepharose CL-6B. A column $(3.2 \times 13 \mathrm{~cm})$ of CM-Sepharose CL-6B was equilibrated with $20 \mathrm{mM}$ acetate buffer ( $\mathrm{pH} 4.4)$. A sample $(158 \mathrm{~mL})$ of the fraction not retained on DEAE-Sepharose CL-6B was dialysed overnight against $\mathrm{mM}$ phosphate buffer ( $\mathrm{pH} 7.0$ ) and then against $20 \mathrm{mM}$ acetate buffer ( $\mathrm{pH}$ 4.4) for $2.5 \mathrm{~h}$ at $4^{\circ}$, and finally applied to the column at $150 \mathrm{~mL} / \mathrm{h}$. After elution with $500 \mathrm{~mL}$ of the starting buffer, a $0 \rightarrow 0.22 \mathrm{M}$ linear gradient of sodium chloride $(700 \mathrm{~mL})$ in the same buffer was applied. The chromatogram is shown in Fig. 1.

(c) On Phenyl-Sepharose CL-4B. Fractions from (b) eluted in the range 0.15$0.20 \mathrm{M}$ were combined $(196 \mathrm{~mL})$, concentrated by dialysis in the presence of Sephadex G 200, dialysed overnight against 10mM phosphate buffer ( $\mathrm{pH} 7.0$ ), diluted with an equal volume of cold $10 \mathrm{~mm}$ phosphate buffer ( $\mathrm{pH} 7.0$ ) containing $2 \mathrm{M}$ ammonium sulphate, applied to a column $(0.9 \times 22 \mathrm{~cm})$ of Phenyl-Sepharose CL4B equilibrated with $10 \mathrm{~mm}$ phosphate buffer ( $\mathrm{pH} 7.0$ ) containing $\mathrm{M}$ ammonium sulphate, and eluted with the starting buffer $(22 \mathrm{~mL} / \mathrm{h})$ for $\sim 2$ column volumes. A linear gradient $(0 \rightarrow 50 \%)$ of aqueous ethylene glycol $(300 \mathrm{~mL})$ was then applied 
with a simultaneous decrease of ammonium sulphate from $\mathrm{M} \rightarrow 0$. The chromatogram is shown in Fig. 2.

(d) On Ultrogel AcA54. - Fractions from (c) eluted by the 20-30\% range of the ethylene glycol gradient were combined $(100 \mathrm{~mL})$, dialysed overnight against $50 \mathrm{mM}$ Tris- $\mathrm{HCl}$ buffer $(\mathrm{pH} 7.2)$ containing $0.15 \mathrm{M}$ sodium chloride, concentrated by dialysis to $7.8 \mathrm{~mL}$, applied to a column $(1.6 \times 87 \mathrm{~cm})$ of Ultrogel AcA54 equilibrated with $50 \mathrm{~mm}$ Tris- $\mathrm{HCl}$ buffer $(\mathrm{pH} 7.2)$ containing $0.15 \mathrm{M}$ sodium chloride, and eluted with the starting buffer at $11 \mathrm{~mL} / \mathrm{h}$. The resulting chromatogram is shown in Fig. 3.

(e) On Concanavalin A-Ultrogel AcA22. - Active fractions from (d) (elution volume, $110-135 \mathrm{~mL}$ ) were combined $(26 \mathrm{~mL})$, concentrated, dialysed against $50 \mathrm{mM}$ Tris- $\mathrm{HCl}$ buffer ( $\mathrm{pH} 7.2$ ) containing $0.1 \mathrm{M}$ sodium chloride and $0.1 \mathrm{mM}$ manganese chloride, added to a column $(0.9 \times 15 \mathrm{~cm})$ of ConA-Ultrogel AcA22 (from IBF) equilibrated with $50 \mathrm{mM}$ Tris- $\mathrm{HCl}$ buffer ( $\mathrm{pH} 7.2$ ) containing $0.1 \mathrm{M}$ sodium chloride and $0.1 \mathrm{~mm}$ manganese chloride, and eluted $(45 \mathrm{~mL} / \mathrm{h})$ for $\sim 4$ column volumes. A linear gradient $(0 \rightarrow 0.1 \mathrm{M})$ of methyl $\alpha$-D-mannopyranoside $(100 \mathrm{~mL})$ in the starting buffer was then applied. The chromatogram is shown in Fig. 4.

Properties. - (a) pH Optimum. The xylanase activity was measured under standard conditions by suspending xylan in citrate-phosphate buffer of various $\mathrm{pH}$ values, instead of $0.1 \mathrm{M}$ acetate buffer, $\mathrm{pH} 4.2$ (Fig. 5).

(b) $\mathrm{pH}$ Stability. The xylanase (6 nkat) was incubated in universal buffer of various $\mathrm{pH}$ values at $30^{\circ}$. After $17 \mathrm{~h}$, the enzyme samples were dialysed against $\mathrm{mM}$ phosphate buffer ( $\mathrm{pH} 7.0$ ), and the residual xylanase activity was measured under standard conditions (Fig. 8).

(c) Temperature optimum. The xylanase activity was measured under standard conditions in the temperature range $20-80^{\circ}$. The medium was heat-stabilised for $5 \mathrm{~min}$ before adding the enzyme (Fig. 6).

(d) Temperature stability. The enzyme (6 nkat) in $0.1 \mathrm{M}$ acetate buffer $(\mathrm{pH}$ 4.2) was maintained at various temperatures $\left(4-80^{\circ}\right)$ for $0.5 \mathrm{~h}$, then the residual activity was measured under standard conditions (Fig. 7).

(e) Kinetic parameters. The activity of the purified xylanase was measured under standard conditions with variation of the final concentration of larchwood xylan from 0.4 to $18 \mathrm{mg} / \mathrm{mL}$. For concentrations $>7 \mathrm{mg} / \mathrm{mL}$, the mixtures associated with Nelson colorimetric assays were centrifuged prior to reading the absorbance at $520 \mathrm{~nm}$, because of the high turbidity due to the xylan. The influence of substrate solubility on $K_{\mathrm{m}}$ and $V_{\max }$ was tested by measuring initial velocities under the following conditions. A solution of larchwood xylan in methyl sulfoxide at $20^{\circ}$ was diluted with water to give methyl sulfoxide concentrations from $10-40 \%$ in standard assays (final xylan concentrations, $0.4-7 \mathrm{mg} / \mathrm{mL}$ ). Methyl sulfoxide did not interfere in the Nelson assay. The data were expressed by the LineweaverBurk reciprocal-plots method (Figs. 9 and 10).

(f) Effect of metal ions. The xylanase activity was assayed under standard 
conditions in the presence of mM metal ions. The effect of metal ions on the Nelson assay was preliminarily tested (Table IV).

(g) Influence of specific inhibitors. The xylanase ( 7 nkat) was incubated for 60 $\min$ at $20^{\circ}$ with the following inhibitors: $N$-ethylmaleimide $(20 \mathrm{mM}$ in $0.1 \mathrm{M}$ phos-

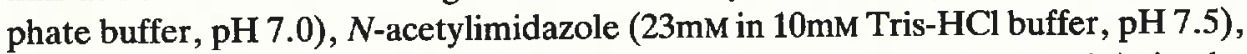
2-hydroxy-5-nitrobenzyl bromide (10mM in $0.1 \mathrm{M}$ acetate buffer, $\mathrm{pH} 4.4$, in the dark), and EDTA (50mM in $10 \mathrm{mM}$ phosphate buffer, pH 7.0). After dialysis for 24 h against $10 \mathrm{mM}$ phosphate buffer $(\mathrm{pH} 7.0)$, the residual activity was measured under standard conditions with an appropriate blank (Table V).

Hydrolysis of the larchwood xylan by the homogeneous xylanase. Larchwood xylan ( $466 \mathrm{mg}$ ) was suspended with stirring in $50 \mathrm{mM}$ acetate buffer ( 50 $\mathrm{mL}, \mathrm{pH} 5.0$ ) containing $0.02 \%$ of $\mathrm{NaN}_{3}$ at $40^{\circ}$. At zero time, homogeneous xylanase solution ( $300 \mu \mathrm{L}, \sim 30$ nkat) was added. After $55 \mathrm{~h}$, when the reducing power of the medium had become constant, the mixture was heated at $100^{\circ}$ for 5 min and then centrifuged, and the supernatant solution was diluted with ethanol to a final concentration of $40 \%$. After centrifugation, the supernatant solution was evaporated to dryness in vacuo at $40^{\circ}$. A solution of the residues in distilled water was deionised with Dowex 1-X8 $\left(\mathrm{HCOO}^{-}\right)$and Amberlite IR-120 $\left(\mathrm{H}^{+}\right)$, and then concentrated in vacuo prior to h.p.t.l.c. and h.p.l.c. (Fig. 11).

\section{ACKNOWLEDGMENTS}

The authors thank J. Vigouroux for technical assistance, Drs. R. R. Selvendran and M. A. O'Neill (Food Research Institute, Norwich, Great Britain) for the amino acid analysis, Professor J.-P. Joseleau (CERMAV, Grenoble, France) for identification of 4-O-methylglucuronic acid, and Dr. Y. Bertheau (Laboratoire de Pathologie Végétale, INRA-INA, Paris, France) for helpful discussions about the electrofocusing procedure.

\section{REFERENCES}

1 R. F. H. DEKKER AND W. A. LiNDNER, South Afric. J. Sci., 75 (1979) 65-71.

2 G. O. Aspinall, in J. Preiss (Ed.), The Biochemistry of Plants, Academic Press, New York, 1980, pp. 473-500.

3 J.-P. Joseleau, in B. Monties (Ed.), Les Polymères Végétaux, Gauthier-Villars, Paris, 1980, pp. 87-121.

4 K. C. B. Wilkie ANd S. L. Woo, Carbohydr. Res., 57 (1977) 145-162.

5 R. F. H. Dekker and G. N. Richards, Adv. Carbohydr. Chem. Biochem., 32 (1976) 277-352.

6 J. COMTAT AND J.-P. Joseleau, Carbohydr. Res., 95 (1981) 101-112.

7 C. J. BaKer, C. H. Whelan, ANd D. F. Bateman, Phytopathology, 67 (1977) 1250-1258.

8 K. Nisizawa, J. Biochem. (Tokyo), 42 (1955) 825-835.

9 K. Nisizawa AND Y. HASHIMOTO, Arch. Biochem. Biophys., 81 (1959) 211-222.

10 K. Nisizawa, I. Morimoto, N. Handa, And Y. Hashimoto, Arch. Biochem. Biophys., 96 (1962) $152-157$.

11 T. Kanda, K. Wakabayashi, and K. Nisizawa, J. Ferment. Technol., 48 (1970) 607-615.

12 T. Kanda, K. Wakabayasil, AND K. NisizaWA, J. Biochem. (Tokyo), 79 (1976) 977-988.

13 T. Kanda, K. Wakabayashi, AND K. Nisizawa, J. Biochem. (Tokyo), 79 (1976) 989-995. 
14 T. Kanda, K. Wakabayashi, And K. Nisizawa, J. Biochem. (Tokyo), 79 (1976) 997-1006.

15 T. Kanda, S. Nakakubo, K. Wakabayashi, and K. Nisizawa, J. Biochem. (Tokyo), 84 (1978) 1217-1226.

16 T. Kanda, K. Wakabayashi, AND K. Nisizawa, J. Biochem. (Tokyo), 87 (1980) 1625-1634.

17 K. E. ERIKSSON AND B. PETtERsson, Int. Biodeterior. Bull., 7 (1971) 115-119.

18 I. V. Gorbacheva And N. A. Rodionova, Biochim. Biophys. Acta, 484 (1977) 79-93.

19 M. G. Paice, L. Jurasek, M. Carpenter, and L. B. Smillie, Appl. Environ. Microbiol., 36 (1978) 802-808.

20 M. M. Frederick, J. R. Frederick, A. R. Fratzke. And P. J. Reilly, Carbohydr. Res., 97 (1981) 87-103.

21 L. L. So and I. J. Goldstein, J. Biol. Chem., 243 (1968) 2003-2007.

22 K. Sumizu, M. Yoshikawa, and S. Tanaka, J. Biochem. (Tokyo), 50 (1961) 538-543.

23 M. Kubackova, S. Karacsonyi, L. Bilisics, and R. Toman, Folia Microbiol. (Prague), 23 (1978) 202-209.

24 V. E. Husemann, J. Prakt. Chem., 155 (1940) 13-64.

25 G. O. Aspinall and J. E. McKay, J. Chem. Soc., (1958) 1059-1066.

26 R. F. H. DekKer And G. N. Richards, Carbohydr. Res., 42 (1975) 107-123.

27 I. M. Morrison, J. Sci. Food Agric., 23 (1972) $455-463$.

28 T. E. Timell, $A d v$. Carbohydr. Chem., 19 (1964) 247-302.

29 N. Nelson, J. Biol. Chem., 153 (1944) 375-380.

30 M. Kubackova, S. Karacsonyi, and R. Toman, Folia Microbiol. (Prague), 21 (1976) $28-35$.

31 L. Taiz and W. A. Honigman, Plant Physiol., 58 (1976) 380-386.

32 J.-M. Brillouet, J.-P. Joseleau, J.-P. Utille, And D. Lelievre, J. Agric. Food Chem., 30 (1982) 488-495.

33 J. F. Sawardeker, J. H. Sloneker, And A. Jeanes, Anal. Chem., 37 (1965) 1602-1604.

34 P. Albersheim, D. J. Nevins, P. D. English, AND A. Karr, Carbohydr. Res., 5 (1967) 340-345.

35 N. Blumenkrantz and G. Asboe-Hansen, Anal. Biochem., 54 (1973) 484-489.

36 R. L. TAYlor AND H. E. CONRAD, Biochemistry, 11 (1972) 1383-1388.

37 F. G. J. Voragen, R. Heutink, And V. Pilnik, J. Appl. Biochem., 2 (1980) 452-468.

38 O. H. Lowry, N. J. Rosebrough, A. L. Farr, and R. J. Randall, J. Biol. Chem., 193 (1951) 265-275.

39 J. H. Pazur, Y. Tominaga, L. S. Forsberg, And D. L. Simpson, Carbohydr. Res., 84 (1980) 103114.

40 R. R. Selvendran, J. F. March, and S. G. Ring, Anal. Biochem., 96 (1979) 282-292.

41 J. L. Buchan and R. I. Savage, Analyst (London), 77 (1952) 401.

42 U. K. LAEMMLI, Nature (London), 227 (1970) 680-685.

43 A. Winter, C. EK, ANd U. B. Andersson, LKB Application Note, 250 (1977) 1-13.

44 J. F. MARCH, Anal. Biochem., 69 (1975) 420-442.

45 M. Dubois, K. A. Gilles, J. K. Hamilton, P. A. Rebers, and F. Smith, Anal. Chem., 28 (1956) 350-355. 
